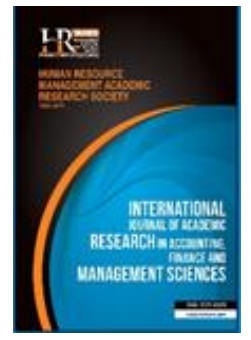

International Journal of Academic Research in Accounting, Finance and Management Sciences

Vol. 8, No.3, July 2018, pp. 209-223

E-ISSN: 2225-8329, P-ISSN: 2308-0337

(C) 2018 HRMARS

www.hrmars.com

To cite this article: Fasan, M., Marcon, C. (2018). Accounting Choice under IFRS: The Role of Accounting Tradition and Managerial Opportunism, International Journal of Academic Research in Accounting, Finance and Management Sciences 8 (3): 209-223.

\title{
Accounting Choice under IFRS: The Role of Accounting Tradition and Managerial Opportunism
}

\author{
Marco FASAN ${ }^{1}$, Carlo MARCON ${ }^{2}$ \\ 1,2Department of Management, Ca' Foscari University, Venice, ${ }^{1} E$-mail: $\underline{\text { marco.fasan@unive.it , }{ }^{2} E \text {-mail: cmarcon@unive.it }}$
}

\begin{abstract}
The present study investigates the role of accounting tradition and managerial opportunism when companies are given by IFRS the option to choose whether to book accounting items following the historical cost or the fair value method. We hypothesize that accounting tradition still plays a role in the choice, with Continental European companies preferring the historical cost and the Anglo-Saxon companies choosing more often the fair value. We also hypothesize that managers will act opportunistically, choosing the historical cost or the fair value method in order to influence the performance of the company and/or their remuneration. By using a hand-collected sample of 480 companies belonging to Continental Europe (Italy, Germany and France) and Anglo-Saxon countries (United Kingdom and Australia) we find support for the first hypothesis while we reject the second hypothesis. Accounting tradition does still play a role in the accounting choice, while managerial opportunism does not.

Key words Accounting choice, accounting tradition, managerial opportunism, fair value, IFRS

Received: 15 Sept 2018 C The Authors 2018

Revised: 25 Sept 2018 Published by Human Resource Management Academic Research Society (www.hrmars.com)

Accepted: 10 Oct 2018 This article is published under the Creative Commons Attribution (CC BY 4.0) license. Anyone may Published Online: 31 Oct 2018 reproduce, distribute, translate and create derivative works of this article (for both commercial and noncommercial purposes), subject to full attribution to the original publication and authors. The full terms of this license may be seen at: http://creativecommons.org/licences/by/4.0/legalcode
\end{abstract}

\section{Introduction}

One of the main aims of the International Accounting Standards (IAS/IFRS) is to foster the harmonization of accounting practices and therefore the comparability of financial statements issued by international companies (Murphy, 2000; De George et al., 2016). National GAAPs provide nonhomogeneous accounting rules, thus hindering the efficiency of capital markets. This paper focuses on accounting choices arising when IFRS allow companies to choose between different accounting methods. In particular, we focused on IAS 40, IAS 38 and IAS 16, which allow companies to choose whether to book the item following the historical cost or the fair value methodology. Accounting choices are central in the accounting debate, as they can potentially decrease the comparability of financial statements. We aim at contributing to the literature investigating the determinants of the choice companies make (Fields et al., 2001).

We test two mechanisms which could influence the choice between fair value and historical cost. The first mechanism is accounting tradition. On the one hand, the stream of literature on accounting tradition (see, among the others, Nobes, 2013) predicts that firms operating in different contexts will make different decisions in terms of accounting choice. The reason for this is that financing, legal and tax systems across the world are different and they lead to different accounting practices that are still influential even when IFRS are in place. Following this line of thought, we would expect Continental European companies to be more likely to choose historical cost, while Anglo-Saxon companies fair value. On the other hand, globalization may have increased the harmonization of accounting practices over time, leading to similar 
accounting practices in the two contexts. The issue of the relevance of accounting tradition, besides being relevant on its own, also suggests that the other determinants of accounting choice may have different impacts in the two contexts, as Anglo-Saxon and Continental European companies are different in terms of models of capitalism and accounting tradition (Leutz et al., 2003; La Porta et al., 2002).

The second mechanism which may explain accounting choice is managerial opportunism. Traditional agency models assume that opportunistic managers are motivated by self-interest and extrinsic rewards. Therefore, they may opportunistically choose historical cost rather than fair value in order to boost the financial performance of their company or even their own remuneration, when based on accounting numbers. In the absence of managerial opportunism, we would not expect the distribution of fair value and historical cost to be random. The IASB gives precise indications to managers in order to guide them in their choice: companies ought to choose fair value when both the relevance and reliability criteria are met (see Huffman, 2018 for a focus on IAS 41). Therefore, we expect companies to follow IASB indications if opportunism is absent.

In order to test our two hypotheses, we rely on a hand collected database, including 480 companies based in Italy, France, Germany, United Kingdom and Australia. Following Nobes (1998) we classify Italy, France and Germany as Continental European countries and United Kingdom and Australia as Anglo-Saxon countries. We read the 2012 annual report of each company in order to code the choice of the company in terms of fair value or historical cost under the three accounting standards: IAS 40 (investment properties), IAS 38 (intangible assets) and IAS 16 (property, plant and equipment). Our empirical results support our first hypothesis as companies located in Continental European countries are significantly more likely to choose historical cost compared to companies located in Anglo-Saxon countries. Conversely, our second hypothesis is rejected: companies generally follow the IASB indications in terms of reliability and relevance criteria and CEO Job security does not play a role in the accounting choice. This empirical evidence is in line with the absence of managerial opportunism playing a role in the choice (Israeli, 2015 instead finds that managerial opportunism does play a role in accounting choices under IAS 40).

Standard setters (namely, the IASB) may find the results of this research of interest because they show that, when accounting principles allow the company to make a choice, the accounting tradition still plays a role in accounting choice, at the cost of homogeneity. Besides, we contribute to accounting choice literature (see Fields et al., 2001 for a review) by testing managerial opportunism (Israeli, 2015). The remainder of the paper is organized as follows: section 2 provides a review of the most important studies we used in framing our article, and section 3 develops our hypotheses. In section 4 we describe the methodology we used in order to test them. Section 5 presents and discusses the results and finally, section 6 concludes.

\section{Literature review}

Following Fields et al. (2001), we define accounting choice as "any decision whose primary purpose is to influence (either in form or substance) the output of the accounting system in a particular way". Scholars began studying accounting choice in the 1960s, with a particular effort in the 1990s and 2000s. We propose a review of previous studies that are relevant for the purposes of this article and in particular we classify such contributions in these two sections: accounting tradition and managerial opportunism.

\subsection{Accounting tradition}

The main benefits arising from the adoption of IFRS are transparency and comparability. IFRS generally allow more accurate, complete and timely financial statement information than local GAAP. Improving financial reporting quality should lead to more informed valuation in equity markets and thus should lower risk to investors. Furthermore, the increased transparency could generate other potential advantages, such as the reduction in a firm's costs of equity capital (Leuz and Verrecchia, 2000; Daske, 2006; Barth et al., 2009), the increase in efficiency of contracting between firms and their managers, with the latter acting more in the interest of the shareholders or between firms and lenders, thereby reducing the cost of debt capital (Watts and Zimmerman, 1986; Ball and Shivakumar, 2005). Additionally, Barth et al. (2008) show that transition to IFRS improves the quality of accounting information by decreasing earnings management, while Jeanjean and Stolowly (2008) find no evidence on reduction of earnings management 
after the transition to IFRS. IFRS also allow improving the comparability of financial statements among companies of different nations. This increased comparability could reduce the cost of processing financial information and therefore is more likely to enhance the efficiency of stock markets in incorporating financial information into prices.

However, the adoption of the same accounting standards does not ensure their uniform application, which is a condition that needs to be met in order to fully exploit the benefits coming from the use of a homogeneous set of accounting numbers. According to the prevalent literature (Ball, 2006; Nobes, 2006; Zeff, 2007), international accounting differences continue to exist in IFRS. Hence, IFRS are not applied consistently among countries with different institutional environments and the harmonization of accounting rules has not led to fully harmonized accounting practices. Notably, inconsistent implementation of IFRS is due to the combined action of some opportunities and some reasons for international accounting differences. Nobes $(2006,2013)$ identifies the following eight aspects of accounting regulation that could determine international differences:

1. Different IFRS versions (Australian IFRS or EU-endorsed IFRS; Zeff and Nobes, 2010; Whittington, 2005);

2. Different IFRS translations due to errors in translation or some non-translatable accounting concepts (Evans, 2004; Baskerville and Evans, 2011; Dahlgren and Nilsson, 2012);

3. Gaps in IFRS - in fact, for topics for which there are no specific rules in IFRS, it is more likely that national accounting traditions will continue as a way of filling any gaps;

4. Overt IFRS options, which are clearly specified as a choice within a standard. IFRS have historically contained more options than most local GAAP because of the negotiations involved in setting standards internationally (Camfferman and Zeff, 2006). Over time, the IASB has gradually removed some options in order to improve comparability, however, the options continue to be numerous;

5. Covert IFRS options, which exist where no explicit choice is permitted but where there is room for management judgment that might allow scope for the preferences of preparers of financial statements. A possible example of a covert IFRS option is the use of cost basis for equity instruments whose fair value cannot be measured reliably (IAS 39);

6. Estimations in IFRS. For example, measurement estimations under IFRS could be biased differently by the different role of accounting conservatism played in different pre-IFRS practices. Over time the need to use estimates to operationalize IFRS has increased;

7. Transitional or first-time adoption issues. First of all, early application of IFRS is usually allowed, so two different versions of the same standard can be in force at the same time. Secondly, IFRS 1 allows entities to choose between several accounting options upon the first instance of IFRS adoption, so different pre-IFRS practices might have a significant impact on IFRS financial statements that could last for many years;

8. Imperfect IFRS enforcement. The degree of the enforcement of rules and therefore compliance with them varies internationally. If companies and auditors are subjected to very little enforcement in a particular country, non-compliance with IFRS is likely to occur (Brown and Tarca, 2005; Berger, 2010, Glaum et al., 2013).

The reasons for the continued occurrence of international accounting differences include some institutional factors that remain primarily local (Ball 2006, Nobes 2006). These country-specific factors are the same forces that drove national GAAP to be different in the pre-IFRS era, such as different financing, legal and tax systems. These local economic and political forces determine the actual behaviour of preparers, auditors, regulators and other parties in the implementation of accounting rules. Research that documents the substantial differences between countries in financial reporting practices that are influenced by local institutional factors include several studies (Ball et al., 2000; Ball et al., 2003; Leuz et al., 2003; Bushman and Piotroski, 2006). This literature also finds evidence that an exogenously-developed set of accounting standards is unlikely to materially change a firm's actual reporting behaviour and financial statement quality. To sum up, national accounting traditions may continue playing a role where the IFRS allow it. Starting from this premise, since 2005 several empirical studies have analysed whether pre-IFRS national practices have influenced accounting policy choice, focusing on some explicit options allowed by IFRS since they are more easily observable. Joos and Lang (2008) find differences in profitability ratios and 
the multiples applied to accounting data in Germany, France and the UK because of diversity in accounting measurement practices. Kvaal and Nobes (2010) examine accounting practices at first-time adoption and find strong statistical evidence that there are national patterns of IFRS practice that undermine comparability. Studies related to specific IFRS policy areas find similar results (Morais, 2008; Fasshauer et al., 2008; Mechelli, 2009), while Cairns et al. (2011) do not find a great difference in the use of fair value between Australia and UK -but this is not surprising given the similarities of their institutional environments. Other studies question whether the influence of pre-IFRS practices was mostly a matter of transition to IFRS and may therefore decrease over time. These studies (Kvaal and Nobes, 2012; Haller and Wehrfritz, 2013) discover few policy changes. However, it is worth noting that, according to Kvaal and Nobes (2012), French and Spanish companies changed their policies more after transition than they had at the first-time adoption. Finally, some studies (Cole et al., 2011; Nobes and Perramon, 2013) investigate the influence on IFRS policy choices exercised not only by the country, but also by industrial sector and company size. Even though some industry- and size-effect has been found, the country remains the most powerful single explanatory variable for a company's IFRS policy choices.

\subsection{Managerial opportunism}

While some studies find that manager's behaviour in shaped by the desire to achieve social norm such as fairness and reciprocity (Bosse and Philips, 2016), traditional agency models assume that opportunistic managers are motivated by the self-interest and the extrinsic rewards. Agency conflicts may be internal (managers-owners) or external (bondholder-shareholder). One of the main instruments to mitigate such conflicts is contract, which often relies on accounting numbers. Since accounting numbers can be influenced by managers through accounting choices, some studies find that managers select accounting methods that increase their compensation and that reduce the likelihood of bond covenant violations (Fields et al., 2001).

Previous literature focusing on internal agency conflict underlines the impact of executive compensation contracts on a firm's accounting choices. Managers are remunerated through short-term or long-term contracts. On the one hand, short-term contracts are often tied to report accounting performance measures such as net income, ROA and ROE. On the other hand, long-term contracts are often tied to stock performance (Fields et al., 2001). The literature on managerial opportunism (Healy, 1985; Guidry et al., 1999; Holthausen et al., 1995; Gaver and Gaver, 1998; Strong and Meyer, 1987; Francis et al., 1996) generally finds evidence that managers will take advantage of the discretion provided by compensation contracts to increase their compensation. Given this result, other studies analyse why bonus contracts allow managerial accounting discretion, reaching different conclusions (Dye and Verrecchia, 1995; Evans and Sridhar, 1996; Watts and Zimmerman, 1986). Other studies deal with external agency conflicts, defined by Fields et al. (2001) as those arising between bondholder and shareholder. The main hypothesis being tested by this literature (Healy and Palepu, 1990; Sweeney, 1994; DeAngelo et al., 1994; DeFond and Jiambalvo, 1994; Nikolaev, 2010) is whether managers select or change accounting methods to avoid covenants violations. Such literature generally finds that there is a relation between accounting choice and debt covenants.

Managers may deliberately use their discretion on accounting choices in order to influence the market value of companies. Studies belonging to this category of accounting choice literature generally test whether the accounting method affects equity valuation or the cost of capital. These studies rely on the work by Ball and Brown (1968), which first documented the association between earnings and share prices. Part of this literature (Beaver and Engel, 1996) is concerned with showing whether markets are efficient.

Literature on the relationship between levels of disclosure and the cost of capital (Botosan, 1997; Sengupta, 1998; Harris, 1998) find mixed results, and there is not clear evidence of a decrease in the cost of capital as a result of accounting choices (increased disclosure). Other studies, finally (Burgstahler and Dichev, 1997; DeFond and Park, 1997), examine whether managers act as if they believe users of financial reporting data can be misled into interpreting reported accounting earnings as equivalent to economic profitability (Fields et al., 2001). More recently, Israeli (2015) finds that contractual and asset-pricing incentives help explain the choice between fair value and historical cost under IAS 40 . Most importantly he concludes that managers are opportunistic in making the recognition versus disclosure choice. 


\section{Hypothesis development}

This section develops the hypotheses being tested in the study. We start by testing whether accounting tradition (still) plays a role in fair value choice. Then, we test whether managers are acting opportunistically in making their accounting choices.

\subsection{Accounting tradition}

Previous literature reviewed above focusing on the role of accounting tradition in the IFRS reporting context (Ball, 2006; Nobes, 2013) generally finds that it plays a role in influencing the accounting choices of companies. The reason for this is that financing, legal and tax systems across the world are different and still influence accounting practices. According to previous studies, local economic and political forces determine the actual behaviour of preparers, auditors, regulators and other parties in the implementation of accounting rules. Conversely, it may be that, over time, the differences in accounting choices due to accounting tradition are less and less relevant, because of globalization and convergence of financial markets. This tension gives rise to a relevant empirical question that is: is accounting tradition still playing a role in managerial accounting choices? Given the greater confidence in the use of fair value in the accounting traditions of Anglo-Saxon countries compared to Continental European countries, we propose the following hypothesis:

Hypothesis 1: Anglo Saxon companies will be more likely to choose fair value, compared to Continental European companies.

\subsection{Managerial Opportunism}

Another potential determinant of the accounting choice is managerial opportunism. Testing the role of managerial opportunism in the context of accounting choices is particularly interesting, because we are focusing on choices that are allowed by the accounting principles rather than on frauds or earnings management. Therefore, as the choices between fair value and historical cost that we are analysing are allowed by the accounting standards, we would expect the choice to be subject to a larger extent to managerial opportunism.

On the one hand, building on managerial opportunism literature, we would expect it to play a role in the accounting choice. Traditional agency models assume that opportunistic managers are motivated by the self-interest. Accounting numbers - that they can, to a certain extent influence through accounting choices - determine their remuneration and reputation. Israeli (2015) finds that IAS 40 accounting choices are motivated by opportunism. The literature on managerial opportunism (Healy, 1985; Guidry et al., 1999; Holthausen et al., 1995; Gaver and Gaver, 1998; Strong and Meyer, 1987; Francis et al., 1996) generally finds evidence that managers will take advantage of the discretion provided by compensation contracts to increase their compensation. Besides, managers may deliberately use their discretion on accounting choices in order to influence the market value of companies (Ball and Brown, 1968).

On the other hand, accounting standards provide some guidance to managers in their accounting choice. In particular, according to the IASB conceptual framework, fair value ought to be used when there are both the conditions of relevance and reliability. According to the IFRS Conceptual Framework for Financial Reporting (march 2018, par. 2.20), "Information must both be relevant and provide a faithful representation of what it purports to represent if it is to be useful. Neither a faithful representation of an irrelevant phenomenon nor an unfaithful representation of a relevant phenomenon helps users make good decisions".

This trade-off between relevance and reliability is central in the accounting choice between fair value and historical cost and should drive managers towards the best decision. For instance, IFRS allows the accounting choice between fair value and historical cost for the measurement of investment property (see IAS 40). Generally, an investment property can be considered having both the requisites of relevance (if it in-exchange, thus does not have any operational ties with other company assets) and of reliability (because it probably has a market value). Therefore, in the absence of managerial opportunism, we would expect non-opportunistic managers to follow IASB indications and choose to measure the investment property at fair value. Consistently with this view, Huffmann (2018) finds that earnings information is more relevant when firms measure in-exchange biological assets at fair value. 
With our second hypothesis we test whether managers are acting opportunistically or rather following the indications of the IASB in the accounting choices realm. We frame our hypothesis according to the managerial opportunism view:

Hypothesis 2: In the context of accounting choice, managers act opportunistically.

\section{Methodology of research}

\subsection{Sample and variables}

We test our hypotheses on a sample of 480 randomly selected listed companies operating in nonfinancial industries. In order to test our hypotheses on the differences in accounting choice between AngloSaxon and Continental European contexts, we selected companies listed in the following countries: Italy, France, Germany, the United Kingdom, and Australia. According to Nobes (1998), Australia and the UK exhibit all the features of Anglo-Saxon accounting, while France, Germany and Italy exhibit all the features of Continental European accounting (Nobes, 1998,). The sample is evenly split between Anglo-Saxon (240 observations - UK and Australia) and Continental European (240 observations - Italy, France and Germany).

In order to study fair value choice by companies in the context of IFRS, we focused on three accounting principles (IAS 40, IAS 38, IAS 16) that explicitly allow companies to choose between historical cost and fair value for non-financial assets.

IAS 40 requires that investment property be measured at subsequent balance sheet dates using either fair value (without depreciation) or the cost model (with depreciation). Under IAS 38, intangible assets are measured after initial recognition using either the cost model or the revaluation model (in restricted circumstances). Under the cost model, items are measured at cost, less any accumulated amortization and impairment losses. Under the revaluation model, items are measured at fair value, less any amortization and impairment losses after the revaluation date. The revaluation model may be used only if the fair value is determined from an active market. Under IAS 16, items of property, plant and equipment are measured after initial recognition using either the cost model or the revaluation model. Under the cost model, items are measured at cost, less any accumulated depreciation and impairment losses; under the revaluation model, the items are measured at fair value, less any subsequent depreciation and impairment losses after the revaluation date. Unlike IAS 38, it is not necessary that fair value be determined only from an active market for the asset. For the purposes of our analysis, we have preferred to distinguish between properties (Land \& Buildings) and Plant \& Equipment, because we expect a different extent of use of fair value measurement.

The variables employed in the analysis are the following:

- IAS 40 - Investment properties, which is an indicator variable with value 1 if the company chose fair value, otherwise 0 ;

- IAS 38 - Intangible assets, which is an indicator variable with value 1 if the company chose fair value, otherwise 0 ;

- IAS 16 - Land \& Buildings, which is an indicator variable with value 1 if the company chose fair value, otherwise 0 ;

- IAS 16 - Plant \& Equipment, which is an indicator variable with value 1 if the company chose fair value, otherwise 0 ;

- Anglo-Saxon, which is an indicator variable with value 1 if the company belongs to U.K. or Australia and 0 otherwise;

- CEO Job security, which is calculated, following Bamber et al. (2010), as the sum of two variables (chairman and directors). Chairman is 1 if the CEO also chairs the board of directors and 0 otherwise. Directors is 1 if the percentage of outside directors on the firm's board is smaller than the sample median and 0 otherwise. This variable measures the job security of the CEO;

- Financial Leverage, the ratio between financial debts and equity;

- Total Assets;

- Price-to-Book, which is the ratio between the market value of the company and its book value; 
- Industry, this variable classifies each company based on its inclusion in one of the 10 ICB industries (Oil\&Gas, Basic Materials, Industrials, Consumer Goods, Health Care, Consumer Services, Telecommunications, Utilities, Financials and Technology).

All the variables refer to the fiscal year 2012, as disclosed in financial statements published in 2013. The two main data sources we employed are the following:

1. Hand collection, for the indicator variables about the fair value choice of companies. The collection was performed by two researchers, who agreed on the criteria to be employed in order to ensure full comparability of results. For instance, in the case where both accounting methods were employed for a certain accounting item (buildings), the researchers coded the variable IAS 16 - Land \& Buildings as 1 if the majority of the assets were booked at fair value and as 0 if not.

2. Bloomberg database, for all the other financial variables.

\subsection{Methodology}

In order to test our first hypothesis, we analyse the descriptive statistics on the percentage of companies choosing fair value or historical cost over the whole sample. In order to assess whether such differences were significant, we performed a logistic regression for each of the accounting principles, including the Fair Value choice as main dependent variable, accounting tradition as main independent variable ( 1 if Anglo-Saxon; 0 if Continental European) and total assets, price to book ratio and financial leverage as control variables (Quagli and Avallone, 2010).

$$
\begin{aligned}
& {\text { IAS } 40_{i j}}=\varphi+\beta_{1} \text { AngloSaxon }_{i j}+\beta_{2} \text { TotalAssets }_{i j}+ \\
& \beta_{3} \text { FinancialLeverage }_{i j}+P 2 B_{i j}+e_{\text {, }}
\end{aligned}
$$

$$
\begin{aligned}
& {\text { IAS } 38_{i j}}_{i j}=\varphi+\beta_{1} \text { AngloSaxon }_{i j}+\beta_{2} \text { TotalAssets }_{i j}+ \\
& \beta_{3} \text { FinancialLeverage }_{i j}+P 2 B_{i j}+e_{\text {, }}
\end{aligned}
$$

$$
\begin{aligned}
& \text { IAS16 }-L \& B_{i j}=\varphi+\beta_{1} \text { AngloSaxon }_{i j}+\beta_{2} \text { TotalAssets }_{i j}+
\end{aligned}
$$

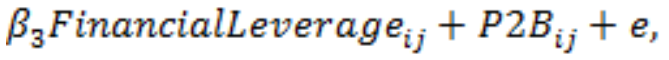

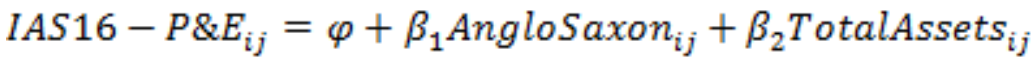

$$
\begin{aligned}
& +\beta_{3} \text { FinancialLeverage }_{i j}+P 2 B_{i j}+e_{\text {, }}
\end{aligned}
$$

In order to test for our second hypothesis, we look at the descriptive statistics about the fair value adoption and we estimate the equations (1) to (4) including the Job Security variable as well as the other control variables. If the accounting choice is driven by managerial opportunism, we would then expect the fair value choice to be influenced by job security. It is likely that manager that is more in danger of losing their job will exploit the choice between fair value and historical cost.

\section{Results and discussions}

Table 1 reports the descriptive statistics for our sample. The number of observations for the indicator variables measuring fair value choice in the four accounting items under analysis is lower than the total number of companies in the sample. The missing observations are either due to the fact that the accounting principle does not apply because the specific item is not present, or to the (rare) cases in which it was not possible to clearly understand the choice made by the company. Table 1 also highlights the extent of fair value use by companies from the whole sample. The accounting principle for which fair value was most often chosen is IAS 40, while none of the companies used the fair value methodology to measure plant and equipment (IAS 16). In fact, only $13.4 \%$ of companies chose fair value for investment properties, substantially ignoring the IASB's clear preference for fair value measurement of this item.

The revaluation model for intangible assets was applied by $3,3 \%$ of companies and this is a little surprising when we take into account that the revaluation model can be used only if the fair value is 
determined by an active market for intangible assets and the findings of other studies show statistics close to $0 \%$ (Cairns et al., 2011).

Table 1

Descriptive Statistics

\begin{tabular}{|c|c|c|c|c|c|c|}
\hline \multicolumn{7}{|c|}{$\begin{array}{l}\text { This table reports descriptive statistics for the variables used in our analyses. We report the mean, standard deviation } \\
\text { and values of the interquartile range for the following variables. IAS } 40 \text { - Investment properties, IAS } 38-\text { Intangible } \\
\text { assets, IAS } 16 \text { - Land \& Buildings, IAS } 16 \text { - Plant \& Equipment are dummy variables with value } 1 \text { if the the company } \\
\text { choose Fair Value, } 0 \text { if the company choose the Historical Cost. Financial Leverage is the ratio between financial } \\
\text { debts and equity. Price to Book is the ratio between the market value of the company and its book value. Total Assets } \\
\text { are the balance sheet assets at the fiscal year end. Job Security is calculated following Bamber et al (2010). All the } \\
\text { variables refer to the Fiscal Year } 2012 \text {. }\end{array}$} \\
\hline Variable & $\mathrm{N}$ & Mean & $\begin{array}{l}\text { Standard } \\
\text { Deviation }\end{array}$ & $\begin{array}{c}1 \text { st } \\
\text { Quartile }\end{array}$ & Median & $\begin{array}{c}\text { 3rd } \\
\text { Quartile }\end{array}$ \\
\hline IAS 40 - Investment properties & 135 & 0.134 & 0.341 & 0 & 0 & 0 \\
\hline IAS 38 - Intangible assets & 442 & 0.033 & 0.181 & 0 & 0 & 0 \\
\hline IAS 16 - Land \& Buildings & 385 & 0.0311 & 0.173 & 0 & 0 & 0 \\
\hline IAS 16 - Plant \& Equipment & 479 & 0 & 0 & 0 & 0 & 0 \\
\hline Job Security & 324 & 0.923 & 0.472 & 0 & 1 & 1 \\
\hline Financial Leverage & 480 & 2.777 & 2.240 & 1.568 & 2.111 & 3.165 \\
\hline Total Assets & 480 & 7,644 & 21,953 & 120 & 626 & 3,352 \\
\hline Price to Book & 480 & 2.238 & 2.444 & 0.903 & 1.460 & 2.597 \\
\hline
\end{tabular}

Consistent with our expectations, we find a different extent of use of fair value measurement between IAS 16 - Land \& Buildings (3.1\%) and IAS 16 - Plant \& Equipment (none). Compared to investment properties (IAS 40), the use of fair value for properties employed in operating activities (land and buildings) is lower, probably because it is less relevant and useful to investors and its accounting procedure is more complex. Overall, despite IASB's strong support for fair value accounting, we unconditionally find little use for fair value measurement in areas where it is optional. It is likely due to the cost of preparing and maintaining the fair value model, the greater volatility introduced in financial statements and the lower reliability in measurement where assets are not traded in active markets (Christensen and Nikolaev, 2013). On the one hand, the limited application of fair value might reassure some financial statement users because it means a lower likelihood of measurement errors or managerial manipulation. On the other hand, the narrow extent of fair value use implies that financial statements provide less value-relevant information, which may be not consistent with the preferences of IASB and the needs of investors.

Table 2

The fair value choice by country

This table displays the frequency of the choice of fair value by country, for IAS 40, IAS 38, IAS 16 (Land \& Buildings), IAS 16 (PPE). For each combination of accounting principle and country, the total number of observations is divided into three categories (NA: the accounting principle is not applicable; Fair Value: the company chose to report the Fair Value; Historical Cost: the company chose to report the Historical Cost). There are 80 observations for Italy, France and Germany; 120 obervations for UK and Australia.

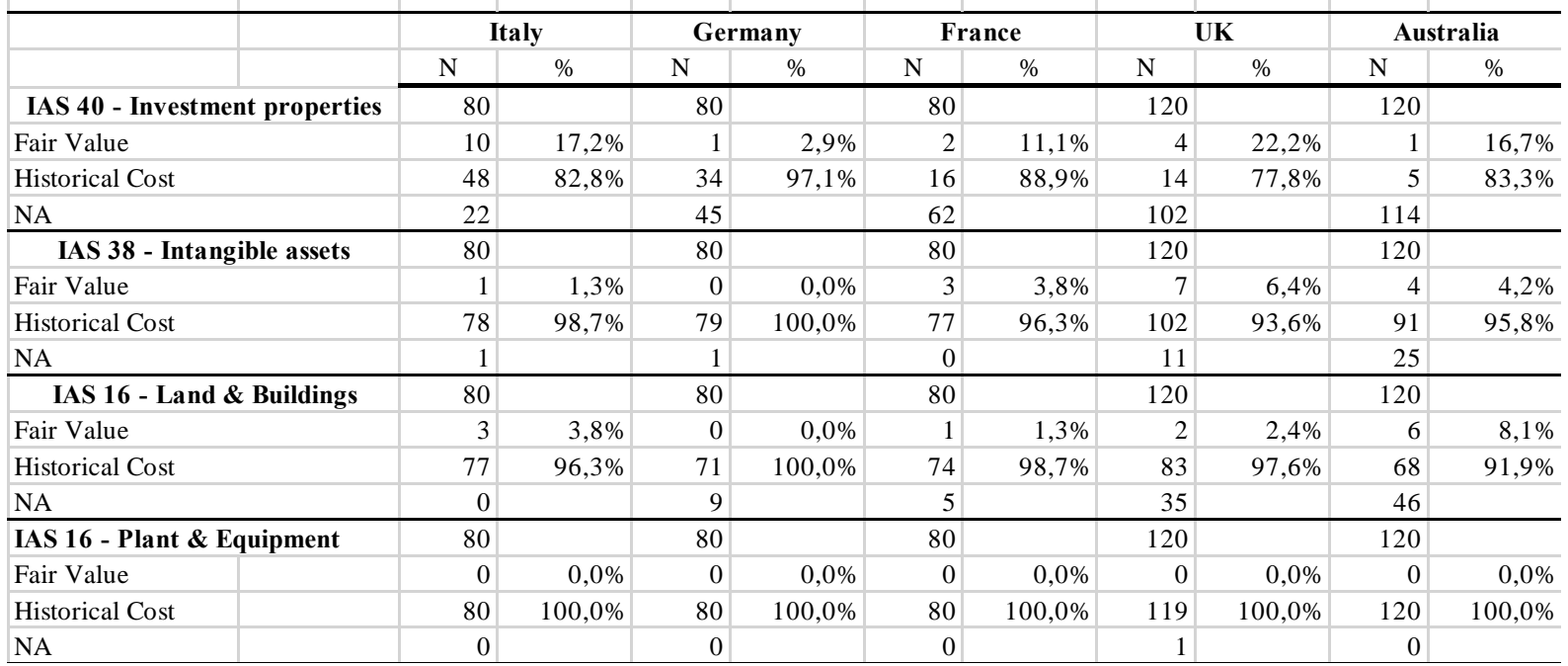


Table 2 displays the descriptive statistics on the fair value choice by country. Overall, German companies are the most conservative in the optional use of fair value measurement, while UK and Australian companies mostly apply the fair value model for investment properties and intangibles assets (the former) and land and buildings (the latter), consistent with their accounting traditions.

Looking at the results for IAS 40 - Investment properties, we see that in many cases the accounting principle is not applicable, especially in the UK and Australia, consistent with the findings of other studies (Cairns et al., 2011; Haller and Wehrfritz, 2013). In these countries, the majority of companies do not have any investment property or they hold it through an operating leasing contract (in such cases, no choice is available to the company). The table reports the number of companies choosing fair value over the number of companies for which the accounting principle was applicable. Our statistics show that $17,2 \%, 2,9 \%$ and $11,1 \%$ of Italian, German and French companies chose fair value against $22,2 \%$ and $16,7 \%$ of UK and Australian companies. These findings reflect the countries' different pre-IFRS accounting practices. In fact, under UK GAAP, investment properties are measured at open market value with no depreciation process but with changes of value recognized in equity. Australian GAAP allowed the choice between the cost model and the revaluation model (both with depreciation). In Italy and in France, an asset revaluation recognized in equity is permitted only under some restricted circumstances (e.g. in Italy, if a special law allows it), while in Germany even no revaluations are allowed.

Also for IAS 38, the percentage of companies choosing fair value in the UK and Australia $(6,4 \%$ and $4,2 \%)$ is higher than the percentage for Continental European companies $(1,3 \%, 0 \%$, and 3,8\%). This is consistent with the history of asset revaluation in the UK and Australia (Barth and Clinch, 1998, show that $21 \%$ of Australian companies reported revalued intangible assets based on data collected in the period 1991-1995). It is interesting to point out that, in the Anglo-Saxon context, there are a higher number of "non-applicable" observations, and this is due to the fact that in many cases the majority of intangible assets are referring to goodwill.

The analysis of IAS 16 - Land and Buildings shows a high number of missing observations in the UK and Australia, due to the fact that many companies hold land and buildings through an operating leasing contract. Among the companies for which the accounting principle was applicable, 3,8\%, $0 \%$ and $1,3 \%$ of Italian, German and French companies chose fair value against 2,4\% and 8,1\% of UK and Australian firms. Actually, in the past, many UK and Australian companies used fair value measurement. However, the application of the revaluation model declined in the UK and Australia from the early 1990s as economies experienced lower inflation and the local GAAP introduced stricter revaluation requirements, as shown by some studies (Parker and Morris, 2001; Tarca, 2005).

Results for IAS 16 - Plant \& Equipment (Cairns et al., 2011; Kvaal and Nobes, 2012; Haller and Wehrfritz, 2013) show that none of the companies in any of the countries chose fair value.

These results provide some preliminary evidence about both our hypotheses. In terms of the impact of the accounting tradition, we see that the average number of companies choosing fair value is lower in the Continental European context compared to the Anglo Saxon Context. When we look at IAS 40, the average number of companies using fair value is 10,4\% in Europe and 19,5\% in UK and Australia; for IAS 38, the average is $1,7 \%$ in Europe and 5,3\% in UK and Australia; for IAS 16 (Lang and Buildings) the average is $2,5 \%$ in Europe and $5,2 \%$ in the Anglo-Saxon context.

If we look at the guidelines provided by the IASB in the Conceptual Framework, we see that the only category of asset that has both the characteristics of relevance and reliability is investment property, as they are in-exchange assets and they are traded in an active market. The other assets, instead, miss either the reliability or the relevance (or both) requisites. Intangibles are usually in-use assets and their measurement lacks reliability. Land, buildings, plant and equipment are often reliably measurable, but they are in-use assets.

It follows that, if we apply IASB indications, we would expect to see a higher number of companies using fair value for investment properties, rather than for the other categories of assets. Empirical data shows that - unconditional on the accounting tradition - $13 \%$ of the companies chose fair value for investment properties while only $3 \%$ chose fair value for intangibles and Land and Buildings. Therefore, we can speculate that managers, in making their accounting choice, followed the IASB indications and did not behave opportunistically. 


\section{Table 3}

\section{Determinants of Fair Value Choice}

This table analyzes the determinants of the Fair Value choice through a logistic regression. The dependent variable is IAS 40 - Investment properties in Model (1), IAS 38 - Intangible assets in Model (2), IAS 16 - Land \& Buildings ni Model (3). AngloSaxon is an indicator variable equal to 1 if the company belongs to Australia or UK, 0 otherwise.

\begin{tabular}{|c|c|c|c|c|c|c|c|}
\hline \multirow{3}{*}{$\begin{array}{l}\text { Variable } \\
\text { Anglo-Saxon }\end{array}$} & \multirow{2}{*}{\multicolumn{2}{|c|}{$\begin{array}{c}(1) \\
\text { IAS } 40- \\
\text { Investment } \\
\text { properties }\end{array}$}} & \multicolumn{2}{|c|}{ (2) } & \multicolumn{2}{|l|}{ (3) } & \\
\hline & & & \multicolumn{2}{|c|}{$\begin{array}{c}\text { IAS } 38- \\
\text { Intangible assets }\end{array}$} & \multicolumn{2}{|c|}{$\begin{array}{l}\text { IAS } 16 \text { - Land } \\
\text { \& Buildings }\end{array}$} & \\
\hline & 1.059 & $*$ & 1.304 & $* * *$ & 1.949 & $* *$ & \\
\hline & $(0.572)$ & & $(0.356)$ & & $(0.317)$ & & \\
\hline \multirow[t]{2}{*}{ Financial Leverage } & 0.253 & $*$ & 0.055 & & 0.383 & $* * *$ & \\
\hline & $(0.139)$ & & $(0.049)$ & & $(0.124)$ & & \\
\hline \multirow[t]{2}{*}{ Price to Book } & -0.203 & & -0.244 & $* * *$ & -0.417 & $* * *$ & \\
\hline & $(0.192)$ & & $(0.062)$ & & $(0.105)$ & & \\
\hline \multirow[t]{2}{*}{ Total Assets } & -0.001 & $* * *$ & 0.001 & & 0.001 & & \\
\hline & $(0.001)$ & & $(0.001)$ & & $(0.001)$ & & \\
\hline \multirow[t]{2}{*}{ Intercept } & -2.321 & $* * *$ & -3.764 & $* * *$ & -4.118 & $* * *$ & \\
\hline & $(0.629)$ & & $(0.328)$ & & $(0.433)$ & & \\
\hline Industry controls & \multicolumn{2}{|l|}{ Yes } & \multicolumn{2}{|c|}{ Yes } & \multicolumn{2}{|l|}{ Yes } & \\
\hline Number of observations & 135 & & 442 & & 385 & & \\
\hline Chi 2 & 17.47 & $* * *$ & 108.69 & $* * *$ & 274.93 & $* * *$ & \\
\hline Pseudo R2 & 0.09 & & 0.06 & & 0.22 & & \\
\hline
\end{tabular}

Table 3 displays the results about the determinants of the fair value choice through a logistic regression. The dependent variable is the indicator variable with value 1 if the company choses fair value and 0 otherwise. The three models (one for each accounting standard with at least 1 observation) are overall significant and have a Pseudo R2 equal to 9\% (Model 1), 6\% (Model 2) and 22\% (Model 3). The control variables (financial leverage and price to book ratio) load consistently with previous studies (Quagli and Avallone, 2010).

The main variable under analysis is Anglo-Saxon that measures, in a multivariate regression model, whether accounting tradition has an impact on the accounting choice. The Anglo-Saxon variable is positive and significant in all the models. In Model 1 has a coefficient of 1.059 and it is significant at the $10 \%$ level; in Model 2 is significant at the $1 \%$ level and has a coefficient of 1.304; in Model 3 is significant at the $5 \%$ level and has a coefficient of 1.949 .

Overall, we can conclude that the evidence displayed in Table 2 and Table 3 confirms our first hypothesis. We find that Anglo Saxon companies are more likely to use fair value, compared to Continental European companies. This shows that the results of the accounting tradition literature (Nobes, 1998, 2006) hold true also in 2012, despite the push towards the harmonization of accounting principles that was partly shown by previous studies. Notably, Kvaal and Nobes (2012) find that the many French and Spanish posttransition policy changes were largely distant from national pre-IFRS practices, suggesting some learning process. IFRS were adopted in 2005 and one of the driving principles of the IASB was to reach comparability of financial statements. In 2012, eight years after the adoption, we find that there are still significant differences in the way IFRS are adopted, making harmonization and comparability difficult. This article focuses on differences in the application of IFRS that are explicitly allowed by those same accounting principles. In the light of the evidence provided by the present article (and by the literature on accounting tradition), standard setters (namely, the IASB) may consider whether it is still appropriate to provide such different possibilities of application of accounting standards.

Table 4 tests, through a t-test, whether the percentage of companies choosing Fair Value under a certain accounting standard is significantly different compared to the percentage of companies employing fair value in another accounting standard. 
Table 4

Significance of Fair Value adoption among the different accounting principles

This table tests (through a t-test) whether the percentage of companies choosing Fair Value in a certain accounting standard is significantly different compared to the percentage of companies employing Fair Value in another accounting standard, the null hypothesis being that the percentages are equal. A positive sign of the t-value indicates that the accounting standard listed in the columns has a higher percentage of companies employing Fair Value, while a negative sign of the coefficient indicates that the accounting standards listed in the rows has a higher percentage of companies employing Fair Value. Fair Value percentage is cumulative percentage of companies employing Fair Value across the five sample countries for each accounting principle.

Levels of significance are indicated by: $* \mathrm{p}<0.15, * * \mathrm{p}<0.10, * * * \mathrm{p}<0.05$

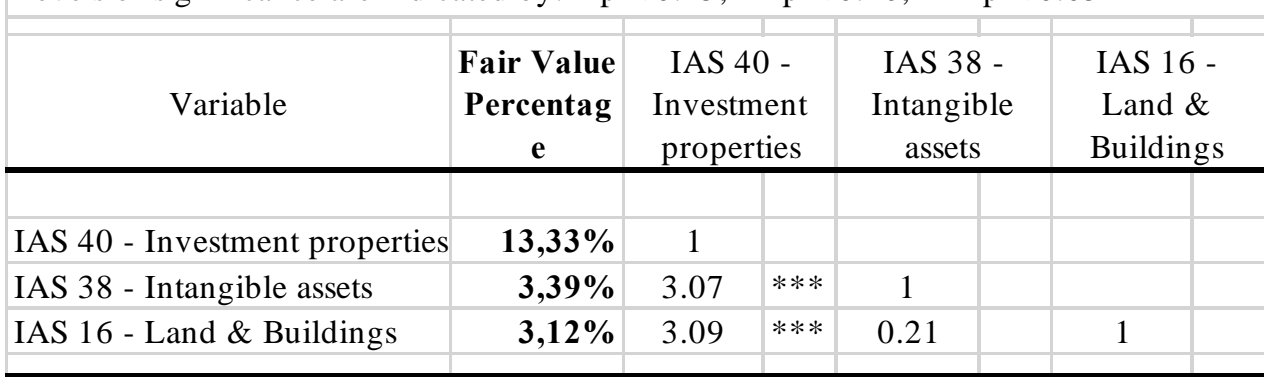

The results displayed in Table 4 further support the rejection of hypothesis 2, as the percentage of companies choosing fair value is statistically significantly higher for investment properties. As suggested before, this result is in line with the indication by the IASB rather than with managerial opportunism, thus providing preliminary evidence for the rejection of hypothesis 2 .

Table 5

The effect of job security on fair value choice

This table analyzes the determinants of the Fair Value (and in particular financial leverage and job security) choice through a logistic regression. The dependent variable is IAS 40 Investment properties in Model (1), IAS 38 - Intangible assets in Model (2), IAS 16 - Land $\&$ Buildings ni Model (3). Anglo-Saxon is an indicator variable equal to 1 if the company belongs to Australia or UK, 0 otherwise.

Levels of significance are indicated by: $* \mathrm{p}<0.10, * * \mathrm{p}<0.05, * * * \mathrm{p}<0.01$

\begin{tabular}{|c|c|c|c|c|c|c|c|}
\hline \multirow{3}{*}{$\begin{array}{l}\text { Variable } \\
\text { Anglo-Saxon }\end{array}$} & \multirow{2}{*}{\multicolumn{2}{|c|}{$\begin{array}{c}(1) \\
\text { IAS } 40- \\
\text { Investment } \\
\text { properties }\end{array}$}} & \multirow{2}{*}{\multicolumn{2}{|c|}{$\begin{array}{c}\text { (2) } \\
\text { IAS } 38 \text { - } \\
\text { Intangible assets }\end{array}$}} & \multicolumn{2}{|l|}{ (3) } & \\
\hline & & & & & \multicolumn{2}{|c|}{$\begin{array}{l}\text { IAS } 16 \text { - Land } \\
\text { \& Buildings }\end{array}$} & \\
\hline & 0.908 & & 1.300 & $* *$ & 1.879 & $* *$ & \\
\hline & $(0.733)$ & & $(0.650)$ & & $(0.311)$ & & \\
\hline \multirow[t]{2}{*}{ Financial Leverage } & -0.384 & & -0.127 & & 0.013 & & \\
\hline & $(0.336)$ & & $(0.104)$ & & $(0.081)$ & & \\
\hline \multirow[t]{2}{*}{ Job Security } & -2.11 & & -1.738 & $* *$ & 0.209 & & \\
\hline & $(1.43)$ & & $(0.769)$ & & $(0.523)$ & & \\
\hline \multirow[t]{2}{*}{ Price to Book } & -1.133 & $* *$ & -0.175 & $* * *$ & -0.410 & $* *$ & \\
\hline & $(0.579)$ & & $(0.034)$ & & $(0.163)$ & & \\
\hline \multirow[t]{2}{*}{ Total Assets } & -0.001 & & -0.001 & & -0.001 & & \\
\hline & $(0.001)$ & & $(0.001)$ & & $(0.001)$ & & \\
\hline \multirow[t]{2}{*}{ Intercept } & 0.589 & & -2.294 & $* * *$ & -2.281 & & \\
\hline & $(1.031)$ & & $(0.805)$ & & $(0.627)$ & & \\
\hline Industry controls & \multicolumn{2}{|l|}{ Yes } & \multicolumn{2}{|l|}{ Yes } & \multicolumn{2}{|l|}{ Yes } & \\
\hline Number of observations & 76 & & 233 & & 117 & & \\
\hline Chi 2 & 531 & $* * *$ & 71 & $* * *$ & 173 & $* * *$ & \\
\hline Pseudo R2 & 0.25 & & 0.14 & & 0.07 & & \\
\hline
\end{tabular}

The statistical analysis displayed in Table 5 aims at providing further empirical evidence about hypothesis 2 . The table shows the results of a multivariate regression in which the dependent variable is 
the choice of fair value in the three accounting standards (IAS 40, IAS 38 and IAS 16) and the independent variables are Anglo-Saxon, Financial Leverage and Price to Book. In particular, in this model we added the CEO Job Security variable, which is capturing the degree to which the CEO has security of his/her job.

The models are overall significant at the $1 \%$ level and they have a Pseudo R2 of 25\% (Model 1), $14 \%$ (Model 2) and 7\% (Model 3). Consistently with previous studies (Quagli and Avallone, 2010) and with our previous analysis (Table 3) control variables loads consistently. Most importantly, we see that the Job Security variable is generally not significant. Only in Model 2, it is significantly (at the $5 \%$ level) and negatively related. This means that CEOs that are more in danger of losing their job do not make accounting choices that are significantly different compared to CEOs that are more immune from threat of dismissal. This evidence is in line with the rejection of hypothesis 2 about managerial opportunism.

\section{Conclusions}

The present study deals with the determinants of fair value choice in different contexts, from an accounting tradition and an opportunistic management perspective.

The first part of the paper analyses whether accounting tradition still plays a role in influencing the accounting choice of companies. Empirical results show that Anglo-Saxon companies are more likely to choose fair value, when compared to Continental European companies, thus confirming the results of the literature on accounting tradition, despite the IFRS being adopted since 2005 (De George et al., 2016 for a review of the IFRS adoption literature).

In the second part of the paper, we test whether managerial opportunism plays a role in shaping the accounting choices of companies. Our empirical evidence excludes this hypothesis (challenging the results obtained by Israeli, 2015) and shows that accounting choices made by managers follows the guidelines by the IASB adopting fair value only when the asset is being used internally together with other assets and there is an external market on which that asset can be exchanged (Linsmeier, 2013).

Standard setters (namely, the IASB) may find the results of this research of interest because they show that, when accounting principles allow the company to make a choice, accounting tradition still plays a role in the accounting choice, at the cost of homogeneity. The result about managerial opportunism allows a further understanding of the determinants of accounting choice that standard setters could take into account when deciding about whether to allow accounting choices and reasoning about accounting choices shortcomings or unintended consequences.

\section{References}

1. Ball, R. (2006), International Financial Reporting Standards (IFRS): pros and cons for investors, Accounting and business research, International accounting policy forum, pp. 5-27.

2. Ball, R., Brown, P., (1968). An empirical evaluation of accounting income numbers. Journal of Accounting Research, 6, pp. 159-178.

3. Ball, R., Kothari, S.P., and Robin, A., (2000). The effect of international institutional factors on properties of accounting earnings. Journal of accounting and economics, 29 (1), pp. 1-51.

4. Ball, R., Ashok, R. and Shuang Wu, J. (2003). Incentives versus standards: properties of accounting income in four East Asian countries and implications for acceptance of IAS. Journal of Accounting and Economics, 36, pp. 235-270.

5. Ball, R. and Shivakumar, L. (2005), Earnings quality in UK private firms, Journal of Accounting and Economics, 39, pp. 83-128.

6. Bamber, L.S., Jiang, J., Petroni K., Wang I. (2010), Comprehensive Income: Who's afraid of performance reporting?, The Accounting Review, 85 (1), pp. 97-126.

7. Barth, M. (2006). Including estimates of the future in today's financial statements. Accounting Horizons, 20, pp. 271-285.

8. Barth, M., \& Clinch, G. (1998). Revalued financial tangible and intangible assets: associations with share prices and non-market based value estimates. Journal of Accounting Research, 36 (Suppl.), pp. 199233.

9. Barth, M.E., Landsman, W.R. and Lang, M. (2008), International accounting standards and accounting quality, Journal of Accounting Research, 46 (3), pp. 467-498. 
10.Barth, M.E., Konchitchki, Y. and Landsman, W. R. (2009), Cost of capital and earnings transparency, Working paper, Graduate School of Business, Stanford University.

11.Baskerville, R. and Evans, L., (2011). The darkening glass: issues for translation of IFRS. Edinburgh: The Institute of Chartered Accountants of Scotland.

12.Beaver, W.H., Engel, E.E., (1996). Discretionary behavior with respect to allowances for loan losses and the behavior of security prices. Journal of Accounting and Economics, 22, pp. 177-206.

13.Berger, A., (2010). The development and status of enforcement in the European Union. Accounting in Europe, 7 (1), pp. 15-35.

14.Bosse, D. and Philips, R. (2016). Agency theory and bounded self-interest, Academy of Management Review, 41, pp. 276-297.

15.Botosan, C.A., (1997). Disclosure level and the cost of equity capital. The Accounting Review, 72, pp. 323-349.

16.Brown, P. and Tarca, A., (2005). A commentary on issues relating to the enforcement of international financial reporting standards in the EU. European accounting review, 14 (1), pp. 181-212.

17.Burgstahler, D., Dichev, I., (1997). Earnings management to avoid earnings decreases and losses. Journal of Accounting and Economics, 24, pp. 99-126.

18.Bushman, R., Piotroski, J. (2006). Financial reporting incentives for conservative accounting: the influence of legal and political institutions. Journal of Accounting and Economics, 42 (1-2), pp. 107-148.

19.Cairns, D., Massoudi, D., Taplin, R., and Tarca, A., (2011). IFRS fair value measurement and accounting policy choice in the United Kingdom and Australia. The British accounting review, 43 (1), pp. 121.

20.Camfferman, K. and Zeff, S.A., (2006). Financial reporting and global capital markets. Oxford: Oxford University Press.

21.Christensen, H. and Nikolaev, V., (2013). Does fair value accounting for non-financial assets pass the market test?. Review of Accounting Studies, 18, pp. 734-775.

22.Cole, V., Branson, J. and Breesch, D., (2011). Determinants influencing the de facto comparability of European IFRS financial statements. SSRN Working Paper.

23.Dahlgren, J. and Nilsson, S.-A., (2012). Can translations achieve comparability? The case of translating IFRSs into Swedish. Accounting in Europe, 9 (1), pp. 39-59.

24.Daske, Holger (2006), Economic benefits of adopting IFRS or US GAAP - have the expected costs of equity capital really decreased?, Journal of Business Finance and Accounting, 33, pp. 329-373.

25.DeAngelo, H., DeAngelo, L., Skinner, D.J., (1994). Accounting choice in troubled companies. Journal of Accounting and Economics, 17, pp. 113-143.

26.DeFond, M.L., Jiambalvo, J., (1994). Debt covenant violation and manipulation of accruals. Journal of Accounting and Economics, 17, pp. 145-176.

27.DeFond, M.L., Park, C.W., (1997). Smoothing income in anticipation of future earnings. Journal of Accounting and Economics, 23, pp. 115-139.

28.De George, T.E, Li, X., Shivakumar, L. (2016). A review of the IFRS adoption literature. Review of Accounting Studies, 21, pp. 898-1004.

29.Dye, R.A., Verrecchia, R.E., (1995). Discretion vs. uniformity: choices among GAAP. The Accounting Review, 70, pp. 389-416.

30.Evans, J., Sridhar, S., (1996). Multiple control systems, accrual accounting, and earnings management. Journal of Accounting Research, 34, pp. 45-65.

31.Evans, L., (2004). Language translation and the problem of international communication, Accounting, auditing \& accountability journal, 17 (2), pp. 210-248.

32.Fasshauer, J.D., Glaum, M., and Street, D.L., (2008). Adoption of IAS 19 by Europe's premier listed companies, ACCA. Research Report No. 100. London: Association of Chartered Certified Accountants.

33.Fields, T. D., Lys, T. Z. and Vincent, L. (2001), Empirical research on accounting choice, Journal of Accounting and Economics, 31, pp. 255-307.

34.Francis, J., Hanna, D., Vincent, L., (1996). Causes and effects of discretionary asset write-offs. Journal of Accounting Research, 34 (Suppl.), pp. 117-134. 
35.Francis, J.R., Khurana, I.K., Martin, X., and Pereira, R., (2008). The role of firm-specific incentives and country factors in explaining voluntary IAS adoptions: evidence from private firms. European accounting review, 17 (2), pp. 331-360.

36.Gaver, J., Gaver, K., (1998). The relation between nonrecurring accounting transactions and CEO cash compensation. The Accounting Review, 73, pp. 235-253.

37.Glaum, M., Schmidt, P., Street, D., and Vogel, S., (2013). Compliance with IFRS 3- and IAS 36related required disclosures across 17 European countries: company- and country-level determinants. Accounting and business research, 43 (3), pp. 163-204.

38.Guidry, F., Leone, A.J., Rock, S., (1999). Earnings-based bonus plans and earnings management by business-unit managers. Journal of Accounting and Economics, 26, pp. 113-142.

39.Haller, A. and Wehrfritz, M., (2013), The impact of national GAAP and accounting traditions on IFRS policy selection: Evidence from Germany and the UK, Journal of International Accounting, Auditing and Taxation, 22, pp. 39- 56.

40.Harris, M., (1998). The association between competition and managers' business segment reporting decisions. Journal of Accounting Research, 36, pp. 111-128.

41. Healy, P., (1985). The impact of bonus schemes on the selection of accounting principles. Journal of Accounting and Economics, 7, pp. 85-107.

42. Healy, P., Palepu, K., (1990). Effectiveness of accounting-based dividend covenants. Journal of Accounting and Economics, 12, pp. 97-123.

43. Holthausen, R., Larcker, D., Sloan, R., (1995). Annual bonus schemes and the manipulation of earnings. Journal of Accounting and Economics, 19, pp. 29-74.

44. Huffman, A. (2018). Asset use and the relevance of fair value measurement: evidence from IAS 41. Review of Accounting Studies, https://doi.org/10.1007/s11142-018-9456-0.

45.Israeli, D. (2015). Recognition versus disclosure:evidence from fair value of investment property. Review of Accounting Studies, 20, pp. 1457-1503.

46.Jeanjean, T. and Stolowy, H. (2008), Do accounting standards matter? An exploratory analysis of earnings management before and after IFRS adoption, Journal of Accounting and Public Policy, 27 (6), pp. 480-494.

47.Joos, P. and Lang, M. (2008), The effects of accounting diversity: Evidence from the European Union, Journal of Accounting Research, 32, pp. 141-168.

48.Kvaal, E. and Nobes, C.W., (2010). International differences in IFRS policy choice. Accounting and business research, 40 (2), pp. 173-187.

49.Kvaal, E. and Nobes, C.W., (2012). IFRS policy changes and the persistence of national patterns of IFRS practice. European accounting review, 21 (2), pp. 343-371.

50.La Porta, R., Lopez-De-Silanes, F., Shleifer, A., Vishny, R. (2002). Investor Protection and corporate valuation. The Journal of Finance, 57 (3), pp. 1147-1170.

51.Laux, C., and Leuz, C. (2009). Fair value accounting: making sense of the recent debate. Accounting, Organizations and Society, 34 (6-7), pp. 826-834.

52.Leuz, C., Nanda, D. and Wysocki, P. (2003) Earnings management and investor protection: an international comparison, Journal of Financial Economics, 69, pp. 505-527.

53.Leuz, C. and Verrecchia, R. E. (2000), The economic consequences of increased disclosure, Journal of Accounting Research, 38 (Supplement), pp. 91-124.

54.Linsmeier, T., (2013). A standard setter's framework for selecting between fair value and historical cost measurement attributes: a basis for discussion of "Does fair value accounting for non-financial assets pass the market test?". Review of Accounting Studies, 18, pp. 776-782.

55.Mechelli, A. (2009), Accounting harmonization and compliance in applying IASB standards: an empirical survey about the first time adoption of IAS 7 by Italian listed firms, Accounting in Europe, 6 (2), pp. 231-270.

56.Morais, A.I., (2008). Actuarial gains and losses: the choice of the accounting method. Accounting in Europe, 5 (1/2), pp. 127-139.

57.Murphy, A., (2000). The Impact of Adopting International Accounting Standards on the Harmonization of Accounting Practices. The International Journal of Accounting, 35 (4), pp. 471-493. 
58.Nikolaev, V., (2010). Debt Covenants and Accounting Conservatism. Journal of Accounting Research, 48 (1), pp. 51-89.

59.Nobes, C.W., (1998). The future shape of harmonization: some responses. European accounting review, 7 (2), pp. 323-333.

60.Nobes, C.W. (2006), The survival of international differences under IFRS: towards a research agenda, Accounting and business research, 36 (3), pp. 233-245.

61.Nobes, C.W. (2013), The continued survival of international differences under IFRS, Accounting and business research, 43 (2), pp. 83-111.

62.Nobes, C.W. and Perramon, J., (2013). Firm size and national profiles of IFRS policy choice. Australian accounting review, 23 (1), pp. 208-215.

63.Parker, R., and Morris, R. (2001). The influence of US GAAP on the harmony of accounting measurement policies of large companies in the UK and Australia. Abacus, 37 (3), pp. 297-328.

64.Quagli, A. and Avallone F., (2010), Fair Value or Cost Model? Drivers of Choice for IAS 40 in the Real Estate Industry, European Accounting Review, 19 (3), pp. 461-493.

65.Sengupta, P., (1998). Corporate disclosure quality and the cost of debt. The Accounting Review, 73, pp. 459-474.

66.Strong, J., Meyer, J., (1987). Asset write-downs: managerial incentives and security returns. Journal of Finance, 42, pp. 643-661.

67.Sweeney, A.P., (1994). Debt-covenant violations and managers accounting responses. Journal of Accounting and Economics, 17, pp. 281-308.

68.Tarca, A. (2005). International convergence of accounting standards: an investigation of the use of IAS options not acceptable under US GAAP. International Journal of Business Studies, 13 (1), pp. 67-86.

69.Watts, R., and Zimmerman, J. (1986). Positive Accounting Theory. Englewood Cliffs, NJ: PrenticeHall.

70.Whittington, G., (2005). The adoption of international accounting standards in the European Union. European accounting review, 14 (1), 127-153.

71.Zeff, S.A., (2007), Some obstacles to global financial reporting comparability and convergence at a high level of quality, The British accounting review, 39 (4), pp. 290-302.

72.Zeff, S.A. and Nobes, C.W., (2010). Has Australia (or any other jurisdiction) 'adopted' IFRS? Australian accounting review, 20 (2), pp. 178-184. 